\title{
KONFLIKT ROSYJSKO-UKRAIŃSKI W ŚWIADOMOŚCI SPOLECZNOŚCI POCHODZENIA POLSKIEGO OBWODU TARNOPOLSKIEGO
}

\author{
THE RUSSIA-UKRAINE CONFLICT \\ IN AWARENESS OF PEOPLE OF POLISH DESCENT \\ IN TARNOPOL REGION
}

\begin{abstract}
Abstrakt
The aim of this article is to show the influence of the revolution - Euromaidan and Russian-Ukrainian conflict started in 2013 - on the consciousness and identity of people of Polish descent living in Ternopil Region of western Ukraine. The society of the Ternopil Region developed new strategies of social life, adapt to the situation of conflict of defining ourselves as citizens of Ukraine - Country at War. The article contains a brief outline of the events associated with Euromaidan, annexation of the Crimea and fighting separatists in the Donbass region. Based on interviews and observations, the autor shows the awareness of Polish descent of a Russian-Ukrainian conflict, describes the emotions associated with the war and its consequences for the respondents. The text is also about various performances of "foreign" in the narratives of the conflict: Russian, separatist, a resident of eastern Ukraine.
\end{abstract}

Key words: Russia-Ukraine conflict; Ternopil Region; identity; war; emotions; people of Polish descent

\section{Streszczenie}

Celem artykułu jest ukazanie wpływu rewolucji - Euromajdanu i konfliktu rosyjsko-ukraińskiego rozpoczętego od 2013 roku na świadomość i opinie ludności pochodzenia polskiego zamiesz-

MARCELINA JAKIMOWICZ, Instytut Etnologii i Antropologii Kulturowej Uniwersytetu Wrocławskiego. Correspondence: marcelina.jakimowicz@gmail.com

This is an Open Access article distributed under the terms of the Creative Commons Attribution 3.0 PL License (creativecommons.org/licenses/by/3.0/pl/), which permits redistribution, commercial and non-commercial, provided that the article is properly cited. (C) The Author(s) 2015.

Publisher: Institute of Slavic Studies PAS [Wydawca: Instytut Slawistyki PAN] 
kałej w zachodniej Ukrainie, na terenie obwodu tarnopolskiego. Tekst zawiera krótki zarys wydarzeń związanych z Euromajdanem, aneksją Krymu i walkami separatystów w rejonie Donbasu. Autorka bazując na rozmowach i obserwacji ukazuje świadomość ludności pochodzenia polskiego o charakterze konfliktu rosyjsko-ukraińskiego, emocje związane z wojną i jej wpływem na życie rozmówców. Tekst podejmuje także ważną kwestię różnych przedstawień „obcego" w narracjach o konflikcie: Rosjanina, separatysty, mieszkańca wschodniej Ukrainy.

Słowa kluczowe: konflikt rosyjsko-ukraiński; obwód tarnopolski; tożsamość, wojna, emocje; ludność pochodzenia polskiego

\section{WSTĘP}

Efektem każdego konfliktu są zmiany społeczne i kulturowe. Ludność żyjąca w jego obrębie wykształca nowe strategie życia społecznego, dostosowuje się do sytuacji i stara się stworzyć nowe mechanizmy adaptacyjne. Kształtują się normy społeczne i kulturowe, które przekazywane są następnym pokoleniom (Kukuczka, 2010, s. 76). Silne emocje wpływają na odbiór rzeczywistości, przykładem takich wydarzeń jest wojna, która nawet dla osób niemieszkających na terenie walk, a w obrębie państwa zaangażowanego w konflikt, jest doświadczeniem granicznym. Konflikt międzynarodowy powoduje radykalizację nastrojów, doprowadza do emocji, które wywierają wpływ na sądy rozmówców, ich tożsamość, wyobrażenia przyszłości (Kabzińska, 1999, s. 92). Przykładem takiego doświadczenia jest Euromajdan, kryzys krymski i konflikt w ukraińskiej części Donieckiego Zagłębia Węglowego i terenów sąsiednich, czyli obwodu donieckiego i ługańskiego, rozpoczęty w kwietniu 2014 roku. Wydarzenia kryzysu Ukrainy, który rozpoczął się pod koniec 2013 roku, wpłynęły na ludność całego kraju, w tym także na mniejszości etniczne i narodowe.

Badania były prowadzone wśród ludności pochodzenia polskiego, byli to potomkowie Polaków pozostałych na tych terenach po II wojnie światowej”. Nie nazywam rozmówców „Polakami” ani „Polonią” na zachodniej Ukrainie, ponieważ dziś w szczególności młode pokolenia nie identyfikują się z polskością. Wspominają o swoich polskich korzeniach, niekiedy posiadają Kartę Polaka, jednak nie uważają, że jest to równoznaczne z byciem Polakiem. Definiują się jako „Ukraińcy pochodzenia polskiego”, „Ukraińcy o mie-

\section{......}

Badania prowadzone były w lipcu i sierpniu 2014 roku wśród mniejszości polskiej wybranych miasteczek i wsi obwodu tarnopolskiego: Brzeżanach, Czortkowie, Monasterzyskach i okolicznych wsiach. Wyjazd odbył się w ramach grantu wewnętrznego Wydziału Nauk Historycznych i Pedagogicznych Uniwersytetu Wrocławskiego. Grant nr 2260/m/KEAK/14 pt. Wpływ zmian granic i współczesnej sytuacji Ukrainy na tożsamość polskiej ludności obwodu tarnopolskiego. Rozmówcami były osoby mające polskie pochodzenie, których rodziny w czasach pojałtańskiej zmiany granic miały możliwość wyjechać do powojennej Polski, jednak z różnych przyczyn pozostały na terenach Ukrainy. W ramach badań przeprowadziłam dwadzieścia rozmów z reprezentantami trzech pokoleń. Przede wszystkim w ramach grantu skupiłam się na I pokoleniu, które urodziło się przed II wojną światową i pamiętało czas pojałtańskiej zmiany granic. W ramach badań rozmawiałam z dziewięcioma osobami należącymi do pokolenia urodzonego przed II wojna światowa, sześcioma z pokolenia urodzonego po wojnie (II pokolenie) i pięcioma z pokolenia III, urodzonego w czasie lub po transformacji ustrojowej, którego dorosłość przypada na czasy niepodległej Ukrainy. Badania dotyczyły wpływu powojennej zmiany granic na tożsamość tej ludności, jednakże ze względu na konflikt i aktualną zmiane granic Ukrainy (aneksja Krymu) dziejące się w tym czasie na wschodzie Ukrainy, postanowiłam w artykule skupić się tylko na wypowiedziach o emocjach i nastrojach związanych z samym konfliktem. Technika badawcza był wywiad narracyjny, który nastawiony był na opowieści i refleksje odnośnie do konfliktu na wschodzie kraju, jednak ze względu na aktualność wydarzeń i obawy związane z rozwojem konfliktu wielokrotnie rozmowy przybierały charakter dynamicznych dyskusji rodzinnych, w które zaangażowani byli wszyscy członkowie rodzin. Dodatkowym materiałem badawczym były notatki terenowe, w których zapisywałam większość odczuć, refleksji związanych z rozmowami. Niektóre z rozmów odbywały się w języku ukraińskim. Wszystkie tłumaczenia autorki. 
szanych korzeniach”, „ukraińscy Polacy”, zaznaczając tym samym specyficzny charakter swojej tożsamości. Tylko w przypadku najstarszego pokolenia, czyli tych, którzy urodzili się przed wojną, następowała identyfikacja z polskością ${ }^{2}$. Tak też mając na uwadze charakter samoidentyfikacji rozmówców, zazwyczaj w artykule używam określenia "ludność pochodzenia polskiego".

W tekście przedstawiono wpływ rewolucji zwanej Euromajdanem, aneksji Krymu i konfliktu międzynarodowego na wschodzie Ukrainy z lat 2013-2014 na świadomość, opinie i emocje ludności pochodzenia polskiego zamieszkałej na zachodniej Ukrainie. Badania prowadziłam w lipcu i sierpniu 2014 roku na terenie kilku miasteczek i wsi obwodu tarnopolskiego ${ }^{3}$. Z początku badania miały dotyczyć pamięci I pokolenia urodzonego przed wojną w rodzinach polskich bądź mieszanych, które miały możliwość wyjazdu na tereny powojennej Polski, jednak podczas spotkań poruszana tematyka II wojny światowej prowokowała rozmowy o aktualnych działaniach wojennych na wschodzie kraju. W ramach rozmów chętnie wypowiadały się także młodsze pokolenia, dlatego zdecydowałam się spróbować opisać emocje i nastroje panujące $w$ rodzinach o pochodzeniu polskim W chwili trwającej na wschodzie kraju wojny. W każdej rozmowie pojawiały się kwestie dotyczące najnowszych wydarzeń, pamięć o polskiej historii tych terenów wpływała na charakter opowieści, przykładem jest traktowanie obu wojen jako ram narracyjnych, np. powojenne migracje polskiej ludności z terenów galicyjskich były porównywane do aktualnych migracji uchodźców z terenów wschodnich Ukrainy. Zazwyczaj rozmówcy wiązali obie wojny, częstokroć posługując się stereotypami, pamięcią komunikatywną przekazywaną w obrębie rodziny bądź w przypadku najstarszych pokoleń, własnymi doświadczeniami z II wojny światowej.

Każde ze spotkań w ramach badań kończyło się dyskusją o aktualnej sytuacji Ukrainy: kryzysie gospodarki państwa, konflikcie rosyjsko-ukraińskim i ruchach separatystów na wschodzie kraju. Miałam wrażenie, że aktualne wydarzenia wiążą się z tak wielkim strachem i niepewnością jutra rozmówców, że nie sposób było ominąć tego tematu podczas spotkań. Mimo że rozmówcy nie mieszkali na terenach objętych walkami, już doświadczyli efektów konfliktu w postaci podwyżek cen artykułów spożywczych, niskiego kursu hrywny, napływających ze wschodnich terenów uchodźców czy też powszechnej mobilizacji mężczyzn do wojska. W artykule przedstawiam emocje, opinie i refleksje rozmówców o konflikcie, który w czasie gdy pisany jest artykut, trwa nadal i nie wiadomo kiedy się zakończy i jakie będą jego efekty. Dlatego nie roszczę sobie prawa do przedstawiania wpływu całego konfliktu na tożsamość rozmówców, a jedynie staram się ukazać chwilowy stan.

W pierwszej części artykułu przedstawiam zarys konfliktu, a następnie opinie rozmówców o charakterze działań zbrojnych na wschodzie Ukrainy. W kolejnym podrozdziale opisuję emocje związane z wojną i jej wpływem na życie społeczności o polskich korzeniach obwodu tarnopolskiego. W ostatniej części zajmuję się przedstawieniami "obcego" w narracjach rozmówców, skupiając się na wizerunku Rosji i wojsk rosyjskich zaangażowanych w konflikt, separatystów i mieszkańców obwodów wschodniej Ukrainy.

\footnotetext{
2 Najstarsze pokolenie, czyli urodzeni przed II wojna światowa, starali się opowiadać po polsku, jednak wielokrotnie w przypływie emocji rozmówcy przechodzili na język ukraiński. Rozmówcy z II i III pokolenia, mimo że starali się opowiadać po polsku, jednak swobodniej czuli się w rozmowie po ukraińsku. Dlatego także transkrypcje rozmówców z II i III pokolenia zostały przetłumaczone.

3 Rozmówców wyszukiwałam poprzez organizacje takie jak oddziały Związku Polaków, następnie metodą kuli śnieżnej pytałam się rozmówców o kolejne rodziny, które mają polskie korzenie.
} 
Historia Ukrainy tworzyła się w wyjątkowo niesprzyjających okolicznościach. Jarosław Hrycak pisze, że gdyby przyjąć, iż naród charakteryzuje się wspólnym językiem, pamięcią historyczną, wyznaniem, okazuje się, że Ukraina nie spełnia ani jednego z tych wyznaczników. Obecnie nieco ponad połowa mieszkańców posługuje się językiem rosyjskim, pamięć historyczna została w czasach Związku Radzieckiego i Ukraińskiej SRR zniszczona, a kilka Kościołów walczy na tych terytoriach o wpływy. Na przestrzeni wieków Ukraińcy byli także poddawani silnemu naciskowi asymilacyjnemu, oprócz tego doznali w XX wieku ogromnych strat w wyniku kataklizmów społecznych (Eberhard, 1994, ss. 184-185). W czasach Związku Radzieckiego świadoma narodowo elita była bardzo nieliczna i nastawiona przeważnie na zachowanie kultury i walke o nią (Hrycak, 2000, s. 12).

Od 1991 roku niepodległa Ukraina została państwem wielonarodowym. Etniczni Ukraińcy stanowią ponad 70\% obywateli, liczbę Rosjan szacuje się na 20\% (Żakowska, 2009, s. 109), oprócz tych dwóch grup państwo zamieszkują także Węgrzy, Rumunii, Polacy i do niedawna Tatarzy Krymscy, którzy dziś po aneksji Krymu w większości znaleźli się na terenie pod władzą Federacji Rosyjskiej. W czasach niepodległej Ukrainy podstawą modelu państwa stało się państwo narodowe opierające się na założeniu, że Ukraińcy stanowią jedyny naród, dla którego ziemie, na których dziś żyją, są rdzennymi ziemiami etnicznymi ${ }^{4}$. Od czasów upadku ZSRR Rosjanie w dyskursach tożsamościowych traktują Ukrainę jako teren dziedzictwa Rusi Kijowskiej, z której historią także się identyfikują (Żakowska, 2009, s. 111.). Polemiki o tym, kto jest rdzennych mieszkańcem Ukrainy, kto przybyszem a kto najeźdźcą czy okupantem, kierują nas do historii i różnej jej interpretacji.

W listopadzie 2013 roku rozpoczęły się protesty społeczne przeciwko odłożeniu przez ówczesnego prezydenta Ukrainy Wiktora Janukowycza podpisania umowy stowarzyszeniowej z Unią Europejską. Opozycja domagała się dymisji prezydenta i nowych wyborów. Sam ruch społeczny zwany Euromajdanem, który wiązał się z manifestacjami i protestami, rozpoczął się w Kijowie. 30 listopada oddziały policji próbowały usunąć protestujących, co wywołało fale oburzenia i powstawanie "nowych Euromajdanów” w większych miastach Ukrainy Zachodniej. Protestujący zajmowali budynki administracji rządowej i samorządowej. Uliczne walki z policją w lutym 2013 roku spowodowały śmierć kilkuset osób, a także stały się punktem zwrotnym. Prezydent Wiktor Janukowycz uciekł z kraju, a parlament zdjął go z urzędu. Natomiast w odpowiedzi na nowe władze w stolicach obwodów wschodniej Ukrainy rozpoczęto prorosyjskie wiece, które popierały Janukowycza - zwane Antymajdanem. Najbardziej gwałtowne wydarzenia miały miejsce na Krymie, gdzie rosyjskojęzyczni Ukraińcy i Rosjanie manifestowali swoją odrębność od reszty Ukrainy. Pojawiły się tendencje separatystyczne, w tym chęć przyłączenia Krymu do Rosji. Na terytorium Krymu doszło do niejawnej interwencji wojsk rosyjskich, natomiast na początku marca 2014 roku Rada Federacji Rosyjskiej jednogłośnie przyjęła wniosek prezydenta w sprawie wydania zgody na użycie rosyjskich sił zbrojnych na terytorium Ukrainy. Kryzys krymski i prorosyjskie manifestacje poprzedziły zbrojne wystąpienia na terenie ukraińskiej części Donieckiego Zagłębia Węglowego. Separatyści ogłosili samozwańczą Doniecką Republikę Ludową i Ługańską Republikę Ludową, które miały znaleźć się w ramach Noworosji. Nowe władze Ukrainy, na czele z prezydentem Petrem Poroszenką, zorganizowały tzw. operację antyterrorystyczną, która miała za zadanie stłumić powstania separatystów i zli-

\footnotetext{
Wyjątek stanowili Tatarzy Krymscy, którzy Półwysep Krymski, do czasów aneksji Krymu przez Federację Rosyjską, traktowali jako autonomię.
} 
kwidować republiki ludowe. Konflikt nadal trwa, mimo podpisywanych kilkakrotnie rozejmów. Podczas badań wszyscy rozmówcy byli pewni, że na wschodzie Ukrainy odbywa się rosyjsko-ukraińska wojna, dlatego także używam takiego sformułowania w tekście.

\section{OPINIE ROZMÓWCÓW O PRZYCZYNACH KONFLIKTU}

Zjawisko zwane biograficzną potrzebą narracji występuje wtedy, gdy dzięki opowieści osoba może nadać sens przeżytym doświadczeniom. Taką potrzebę w szczególności wzbudzają doświadczenia graniczne, mające ogromny wpływ na życie poszczególnych osób jak i zbiorowości (Kabzińska, 1999, s. 83). Będąc na badaniach w obwodzie tarnopolskim, zaobserwowałam ogromny strach rozmówców, którzy kierowali każdą rozmowę w stronę aktualnych wydarzeń, czyli tego, co dla nich było w danym momencie najważniejsze, co ich przerażało, o czym myśleli. Dlatego także bliskie są mi słowa Clifforda Geertza, który zaznaczył, że nie możemy przeżyć życia innych ludzi, możemy tylko słuchać, co oni sami mówią o swoim życiu. Cokolwiek odczuwamy podczas badań wobec życia innych, dochodzimy do tego dzięki zastosowanym przez nich środkom wyrazu, a nie dzięki wtargnięciu do ich świadomości (Geertz, 2011, s. 393), zrozumieniu ich uczuć. Tak też podczas badań mogłam „tylko” słuchać tego, co mówili napotkani ludzie.

Wydarzenia zwane Euromajdanem i konflikt na wschodzie Ukrainy stały się źródłem weryfikacji i krystalizacji tożsamości etnicznej i narodowej, wzmocniły także poczucie więzi i solidarności z własną grupą (Kabzińska, 1999, s. 96).

Ciekawym procesem jest upowszechnianie się symboli narodowych w przestrzeni publicznej, zauważane od początków konfliktu. Na całej zachodniej Ukrainie od czasu wybuchu Euromajdanu w domach i na podwórzach można było zobaczyć symbole narodowe, które naznaczały przestrzeń i wskazywały na identyfikację z ukraińską stroną konfliktu. Symboliczne wsparcie dla ukraińskich, proeuropejskich dążeń zaznaczane było poprzez: noszenie wstążek w barwach flagi państwowej na nadgarstku, przy torbach i plecakach; flagi ukraińskie umieszczane w przestrzeni domu; malowanie na żółto-niebiesko studnie czy rury doprowadzające gaz, aż po bojkot produktów pochodzących z firm rosyjskich. W przestrzeni publicznej owe symbole budowały, jak wspominali rozmówcy, poczucie wspólnoty, walkę o dobro kraju. Wielokrotnie zaznaczano, że Ukraina, mimo że wieloetniczna, to $w$ chwili wojny powinna się zjednoczyć. Podczas prowadzenia badań można było zauważyć identyfikację rozmówców mających polskie korzenie z państwem ukraińskim. Wojna spowodowała, że częściej mówiono "my” jako obywatele Ukrainy. Wyrażało się to w sformułowaniach: "Czego oni od nas chcą?", "zaatakowali nas", "mordują naszych".

W rozmowach dominował sąd, że bez pomocy Zachodu Ukraina nie wygra starcia. Wydarzenia od czasów Euromajdanu i zdymisjonowania prezydenta Wiktora Janukowycza były opisywane przez rozmówców jako rewolucja, która jest szansą na zmianę mentalności obywateli Ukrainy. W konflikcie widziano nadzieję na zjednoczenie różnorakich części tożsamości ukraińskiej. Wielokrotnie odwoływano się do postaci byłego prezydenta jako głównego winnego sytuacji w kraju, ale i postaci, której decyzje zjednoczyły ludzi w czasie Euromajdanu. W opowieściach pojawiała się postać byłego prezydenta Janukowycza i jego rządu jako zdrajców, którzy wykorzystali swoją władzę by, jak mówili rozmówcy, sprzedać Ukrainę Rosji: 
Rosja chce, by Ukraina i prybałtyka była pod Rosją. Oni chcą dalej to wszystko połączyć ze sobą, ale już ludzie się sprzeciwiają. Ten Janukowicz, to wojsko całe oddał ruskim, teraz bandy przyszły i nie ma się czym bronić. I wszystko zniszczył. U nas [na zachodzie] Bogu dzięki jeszcze spokój. Tak Krym już zabrali. Jeszcze chcą Donieck, Ługańsk i tam jeszcze dużo chcą zabrać. Tamte obwody przy granicy z Rosją chcą zabrać, a jaka granica poza Donbasem będzie? To nie wiadomo. A Putin by swoim ludziom, tam w Rosji dał choć żyć dobrze, a tam ludzie bidują. Jeszcze tu w Ukrainie wojnę zaczął ${ }^{5}$.

W przytoczonych słowach zauważamy współczucie dla rosyjskiej ludności, która według rozmówcy jest biedna ale także rządzona „twardą ręką”. Według rozmówców myśl imperialna władzy rosyjskiej ma powodować, iż większość społeczności zamieszkałych na terenach znajdujących się w sferze wpływów Rosji żyje biednie, ich sytuacja materialna stale się pogarsza. Prezydent Federacji Rosyjskiej wielokrotnie w opowieściach nazywany był „wariatem”, „mordercą”, „szaleńcem, który za wszelką cenę chce odbudować imperium". Według rozmówców jego brak szacunku wobec własnego narodu miał charakteryzować władzę Rosji przez wieki:

Ogromny kraj, ale co tam Moskwa? Tam bliżej Europy to jeszcze żyją ludzie, ale dalej to bieda i jeszcze Ukrainę chce zabrać! Tam gdzie wojna teraz, tam kopalnie, fabryki w Ługańsku, Doniecku. Tu [na zachodzie Ukrainy] chleb się rodzi, tam węgiel wydobywają, tam przemyst, maszyny budują. On chce to zabrać do siebie, a tam u niego bida. Co zrobimy? Nie wiemy, jak będzie. Biją się ale co z tego wyjdzie? Nie znamy. Żołnierze nasi nie mają zbroi, kamizelek, tych na głowę kasków nie ma [dla nich], jaka to armia!? Teraz znowu mobilizacja, zabierają ludzi, chłopów na wojnę. A oni nie mają czym strzelać, nie mają co jeść! Nie mają w co ubrać, ale biorą ich! Ja nie wiem, jak to będzie czy świat pomoże, dać trochę ubrania dla tych kozaków wszystkich? Nie wiemy, jak to będzie ${ }^{6}$.

W opowieściach rozmówców drugim powodem zaangażowania Federacji Rosyjskiej w konflikt miały być względy ekonomiczne. Zaznaczano podobieństwo strategii władz rosyjskich w zdobywaniu kolejnych terytoriów dawniej należących do Związku Radzieckiego. Jako przykłady podawano wojnę gruzińsko-rosyjską, konflikt mołdawsko-naddniestrzański, we wszystkich tych konfliktach, według rozmówców, władze rosyjskie wykorzystywały różnorodność etniczną w argumentacji zaangażowania się w konflikt. Rozmówcy, podając przykłady grup narodowych i etnicznych, które doświadczyły krzywdy w związku z imperialną polityką Rosji, ukazywali szersze zjawisko, nie tylko krzywdy danego narodu, ale poczucia ogólnoludzkiej niesprawiedliwości.

Doświadczenie krzywdy związanej z działaniami wojennymi, jak pisze Iwona Kabzińska, zarówno w wymiarze zbiorowym jak i jednostkowym leży często u podstaw wizerunku własnej grupy oraz „innych' i „obcych”, przyczynia się do radykalizacji tych wizerunków (Kabzińska 1999, s. 97). To poczucie niesprawiedliwości rodzi uprzedzenia, które istnieją w pamięci pokoleń przez wiele lat. Według niektórych rozmówców powody wymieniane przez Federację Rosyjską dla argumentowania wkroczenia wojsk na teren wschodniej Ukrainy, czyli obrona rosyjskojęzycznej ludności, są "farsą", "kłamstwem Putina”, "bezczelnym pretekstem" do zajęcia przemystowych terenów Ukrainy:

Ukraina dostała od Putina 15 miliardów za to, że będzie miał wpływy w Donbasie i Putin nie odpuści, bo on włożył 15 miliardów. To jak Arabowie wojowali za naftę, to u nas też tak wojują, za coś a nie za ludzi [śmiech - dop. M. J.]. Niby za wolność walczą, za ludzi a faktycznie za złoża, przemysł ${ }^{\top}$.

\footnotetext{
5 Mężczyzna, I pokolenie (urodzeni przed II wojną światową), Haluszczyńce, wywiad prowadzony w języku ukraińskim.

6 Kobieta, I pokolenie, Haluszczyńce.

7 Kobieta, II pokolenie (urodzeni po II wojnie światowej), Czortków.
} 
Jednak nie wszyscy rozmówcy odrzucali rolę prorosyjskiej ludności wschodniej Ukrainy i jej poparcie dla ruchów separatystycznych w konflikcie. Podział na wschodnią i zachodnią mentalność, rozdźwięk pomiędzy zachodnią a wschodnią Ukrainą pojawiał się wielokrotnie w rozmowach. Na te różnice zwraca uwagę także w esejach Mykoła Riabczuk, który jedną ze swoich książek nazwał "Dwie Ukrainy". Ukazuje w niej, jak bardzo odmienne są terytoria Ukrainy, nie tylko ze względu na wpływy językowe (Ukraina zachodnia, w której dominującym językiem jest ukraiński, i Ukraina wschodnia, w której powszechny jest język rosyjski), ale także różni te społeczności historia i mentalność. Problem jednak nie jest tak prosty, zostaje przecież także centrum, które mimo, iż w większości rosyjskojęzyczne to swoimi upodobaniami politycznymi bliższe jest "nacjonalistycznej" Ukrainie. Nie ma raczej do czynienia z walką dwóch modeli narodowej tożsamości: etnicznym i obywatelskim, ale z walką dwóch etnicznych tożsamości: narodowo-ukraińskiej i wschodniosłowiańskiej (Riabczuk, 2004, ss. 29-30). W rozmowach zazwyczaj zaznaczano różnice w mentalności i dziedzictwie mieszkańców zachodniej i wschodniej Ukrainy, niektórzy powoływali się na nie w zarysowywaniu charakteru konfliktu:

To jest w mózgu człowieka już założone. Zachód inny, bo Polacy tu byli, bo Austriacy byli. Tam była Moskwa, inne poglądy, inna psychologia, inna mentalność, przyzwyczajenie. Wszystko inne a człowiek jest człowiek, jest słaby. Oni tam przyzwyczaili się do mentalności sowieckiej i im się wydaje, że tak ma być a jeszcze ta agitacja, że na zachodzie banderowcy mieszkają, tu już dawno banderowców nie ma, tu spokojnie, kulturalnie. A jeszcze tam na wschodzie mówią, że tu banderowcy, że tu źli ludzie. A lud się boi, wierzy rosyjskim mediom i propagandzie. Putin jak się tylko rozpadł sojuz, powiedział: „Źle, że puściłem Ukrainę" i teraz wykorzystuje te podziały w Ukrainie, by ją zdobyć ${ }^{\text {. }}$

Sytuacja Ukrainy szczególnie po wydarzeniach najnowszych: Euromajdanie, aneksji Krymu i walk separatystów w Donbasie ukazuje, iż jest ona podzielona pod wieloma względami wzdłuż dwóch etnicznych tożsamości. Podstawowym źródłem ambiwalencji społecznej jest zderzenie się dwóch systemów politycznych, gospodarczych i kulturowych. Do tego zderzenia doszło na początku lat 90., kiedy upadł Związek Radziecki wraz z jego ideologią. W sferze ideologicznej tożsamość człowieka radzieckiego spotkała się z identyfikacją narodową, ukraińską. Lata kształtowania tożsamości radzieckiej na Ukrainie oraz wysiłki elit w celu stworzenia narodowej tożsamości ukraińskiej opartej na ciągłości historycznej są konfrontacją dwóch przeciwstawnych systemów wartości i przyczyną dzisiejszych konfliktów w państwach byłego ZSRR (Studenna, 2009, ss. 104-105). Podział "my” i „oni” nie odnosit się tylko do mieszkańców wschodnich terenów Ukrainy, ale przede wszystkim dotyczył "agresorów”, czyli rosyjskich wojsk i separatystów zaangażowanych w konflikt na wschodzie Ukrainy. Ważnym kontekstem rozmów były emocje: strach, złość, czy obrzydzenie, o których rozmówcy częstokroć mówili wprost.

\section{STRACH, NIEPEWNOŚĆ JUTRA I "CZARNE SCENARIUSZE". EMOCJE W OPOWIEŚCIACH ROZMÓWCÓW}

Dzieje doświadczone będące rodzajem świadomości historycznej danej grupy są tzw. małymi historiami, które wpisują się w wielką historię narodów czy państw. Opowieści te oparte są na wydarzeniach osadzonych w pewnym kontekście historycznym, jednak za-

\footnotetext{
-.....

8 Kobieta, II pokolenie, Czortków.
} 
wierają informacje o subiektywnych reakcjach członków społeczności na wydarzenia, zawierają ich doświadczenia i odczucia (Kabzińska, 1999, s. 82). Przykładem jest wojna, która powoduje poczucie chaosu, wprowadza niepewność przyszłości, wpływa negatywnie na życie całej społeczności, oddziałuje także na sferę emocji. Podczas badań wspominano o tym, że wspólnie zasiada się przed telewizorem, dyskutuje o aktualnych informacjach ze wschodu Ukrainy - wojna jest stałym elementem życia codziennego. Nie dotyczy ona rozmówców bezpośrednio, ponieważ nie mieszkają na terenach objętych walkami, ale jednak wpływa na ich życie, na ich wyobrażenia dotyczące przyszłości, niepewność dnia jutrzejszego. Jak pisze Piotr Filipowski, sposób narracji polegający na podmiocie zbiorowym jest specyficzny dla zbiorowych doświadczeń granicznych (Filipowski, 2010, s. 77). Na poziomie konstrukcji językowej można zauważyć, że gdy mówią o konflikcie, operują zaimkiem „my”. Rozmówcy zaznaczali, że wojna powoduje niepewność przyszłości i rzutuje na podejmowane decyzje. Jedna z młodych kobiet wspomniała, że każdy, kto ma Kartę Polaka, rozważa wyjazd do Polski, w sytuacji gdy wojna będzie obejmowała kolejne terytoria:

Niby nikt nie mówi tego wprost, ale w rozmowach prywatnych moi znajomi zaznaczają, że W razie gdy wojna przyjdzie, to pojadą za granicę, tam gdzie ktoś z rodziny pracuje czy żyje. Ważne jest to, że takie myśli nadchodzą a kiedyś ich nie było. Ja jestem po ślubie, mam pracę i normalnie bym myślała o dziecku ale mąż wojskowy. Czeka na przydział, to o jakim dziecku tu mówić, gdy jego plecak czeka spakowany w kącie, a ja modlę się by go przydzielili do jednostki w spokojnym miejscu! Już ustaliliśmy, że jak będzie trzeba, to jedziemy do Polski, bo tam mam dalszą rodzinę ${ }^{9}$.

Wszechobecne poczucie niepewności jutra wpływa na decyzje życiowe młodych ludzi, którzy opowiadali o tym, że mimo planów nie zaczynają budowy domu, nie starają się o dziecko, ale czekają, ",bo nie wiadomo co to będzie, czy konflikt się kiedyś zakończy, czy będzie trwał latami"10. Wspominano, że przed konfliktem na Ukrainie także "nie żyło się lekko”, ale teraz: „żyje się po to, tylko by żyć, sami się dziwimy, że jeszcze jakoś żyjemy. Emerytury wypłacają z opóźnieniem, na wschodzie już nie wypłacają"11.

Kolejnym obliczem strachu związanego z konfliktem na wschodzie jest strach przed mobilizacją mężczyzn do wojska. Zdjęcia w ukraińskiej telewizji ukazujące zniszczenia domostw, fabryk, a także pokazujące ciała ofiar, jak mówią rozmówcy, świadczą o prawdziwym obliczu tego konfliktu. Jak mówił jeden ze starszych mężczyzn:

My z żoną na emeryturze, teraz siedzimy całymi dniami i oglądamy wiadomości. Siadamy przed telewizorem i dyskutujemy. Boimy co to będzie, u nas wszystko na gaz, ludzie poniszczyli piece, uzależnili się od gazu. My teraz nie wojny się boimy, ale początku zimy, bo nie wiadomo jak będziemy się grzać a strach przed wojną, która może się rozpętać przychodzi później. Teraz to o następnych dniach myślimy, jak tu przeżyć. A potem nachodzi nas myśl, że syn jest i wnuk, to do wojska go wezmą i wróci w trumnie jak inni. I wtedy strach taki czuje jak kiedyś, jak wojna była za czasów młodości²

Judith Butler pisze, że obrazy wojny, do których w dzisiejszych czasach za pomocą mediów mamy stały dostęp, uzmysławiają nam kruchość życia, narażenie życia innych na przemoc i tymczasowość stanu spokoju. Wprowadzają także refleksję o kruchości własnego życia i najbliższych, a zarazem zasadę równości wobec zranienia (Butler, 2011,

9 Kobieta, III pokolenie (ur. w niepodlegtej Ukrainie), Tarnopol.

10 Kobieta, III pokolenie, Czortków.

11 Mężczyzna, I pokolenie, Czortków.

12 Mężczyzna, I pokolenie, Czortków. 
s. 21). Rozmówcy mówili, że wojna „jeszcze nie doszła” do terenów Ukrainy Zachodniej, jednak to, co dzieje się na wschodzie kraju, przeraża ich, ponieważ nie wiedzą, jaki będzie koniec konfliktu. Jak wspomina jedna z kobiet, z powodu mobilizacji mężczyzn do wojska i obrazów wojny w telewizji, nie wątpi w to, że działania na wschodzie to międzynarodowy konflikt, który będzie trwał latami:

Na wschodzie by się mogli pogodzić. Ja to zawsze oglądam w telewizji, że tam tylu ludzi zabijają. Jakoś z czwartku na piątek dziewiętnastu Ukraińców zabili a gdzieś z trzydziestu było rannych i ja tak mówię: Po co te dzieci giną?! Ta dajcie im to, co oni chcą, ten Ługańsk, i ten Donieck. Chcą iść do Rosji, niech idą do Rosji. Na co tych ludzi niszczą? I same tam młode dzieci giną. Przyjdą i po naszych chłopców z zachodu, bo to się szybko nie skończy13.

Obrazy ofiar wojska ukraińskiego i informacje o powszechnej mobilizacji do wojska powodują strach o najbliższych. Wojna z telewizora zaczyna być tą, która zabiera ofiary także z otoczenia rozmówców. Niektórzy mówili o tym, że Ukraina nie ma wyboru, musi walczyć, mimo że znajduje się w kryzysie ekonomicznym. Wielokrotnie słyszałam, że nowe władze zmuszone są walczyć o wschodnie tereny, ponieważ w przeciwnym razie siły rosyjskie wraz z separatystami będą zajmować kolejne części państwa:

Jest taka myśl, żeby oddać [te tereny], ale on przyjdzie tutaj, jemu będzie mało. Od razu na zachód by nie przyszedł, tam oni sami na wschodzie dopuścili do tego. My myśleliśmy, że tam zwykli ludzie walczą, ale tam bandyci, strzelają, rabują. Kto tam przyszedł pomagać separatystom? Czeczeńcy przyszli ich wyzwalać. Tam Azja walczy, tam inna wiara, inna rasa! ${ }^{14}$

Wszyscy rozmówcy śledzili na bieżąco wydarzenia we wschodniej części Ukrainy. W ukraińskiej telewizji zdjęcia ofiar, poniszczonych budynków szkół i szpitali, grupy uciekających cywilów były powszechne. Jak pisze Susan Sontag, wojna jest uniwersalna, uogólniona, a obrazy z wojny są zdjęciami uogólnionych, anonimowych ofiar. Sprzeciw wobec wojny nie wymaga dokładnych informacji o tym kto zginął, a kto atakował i gdzie. Przypadkowość ataków i śmierci jest wystarczającym argumentem. Dla ludzi, którzy są przekonani, że rację ma jedna strona, a druga jest sprawcą ucisku i niesprawiedliwości, wystarczy tylko potwierdzenie w obrazach i informacjach tego wyobrażenia (Sontag, 2010, ss. 16-17).

Uznanie cierpienia ofiar, pamięć o nich jest ważnym elementem przekształceń społecznych, które są powiązane z polityczną zmianą systemu i kształtowaniem tożsamości ukraińskiej. Możemy to zauważyć na przykładzie ukraińskiego dyskursu o bohaterach i ofiarach starć z Berkutem na Euromajdanie czy też w postaciach mariupolskiej ludności cywilnej, która broniła miasto przed separatystami albo żołnierzy ukraińskich broniących lotniska w Doniecku, którzy nazwani zostali „niezniszczalnymi”. Sontag pisze, że skrajne cierpienie związane z wojnami pokazywane w mediach to "coś więcej" niż cierpienie, to „przeistoczenie” (Butler, 2011, s. 110). W przypadku gdy oglądający obrazy z wojny identyfikuje się z tożsamością ofiar, traktuje te osoby jako bohaterów (Sontag, 2010, s. 118). Ofiary, które stają się bohaterami Ukrainy, potrzebne są do budowania nowej tożsamości opartej na wspólnej przeszłości (Assmann, 2013, s. 266). Już od czasów rozwoju nacjonalizmów zakorzenit się ideał osiągnięcia przeznaczenia narodowego poprzez indywidualną bądź zbiorową ofiarę i stał się zasadniczym elementem tożsamości narodowej (Smith, 2009, ss. 66-67).

13 Kobieta, I pokolenie, Haluszczyńce.

14 Mężczyzna, I pokolenie, Haluszczyńce. 
Podczas rozmów zaznaczano, iż Ukraina musi przeżyć rewolucję godności, musi pokazać swoją dumę, co wymaga zmiany mentalności Ukraińców, ponieważ bez „prywatnej rewolucji godności" niepodlegte państwo ukraińskie nie powstanie. W rozmowach pojawiała się kwestia zmiany sposobu myślenia Ukraińców: szacunku narodu wobec samego siebie i odrzuceniu mentalności ukształtowanej za czasów Związku Radzieckiego. W refleksjach rozmówców pojawiała się kwestia prywatnych rewolucji, które powinny dokonywać się w życiu zwykłych ludzi:

O tej rewolucji mówią jako o rewolucji godności, to każda osoba musi dbać o swoją godność. Ta cała bieda Ukrainy polega na tym, że nie każdy ma tą swoją godność i trzeba tą rewolucję godności przeprowadzić u siebie. Moja godność, godność mojego otoczenia. [...] A do tej pory, ten zajmuje jakieś stanowisko, to kłaniają się mu w pas. Ten jest zuchwalszy, to trzeba się mu kłaniać i tak się kłaniają, te łapówki pchają, nie chcą nawet pomyśleć, że można inaczej [zrobićc. Takie sprawy jak dostanie się na studia. Oni nie wierzą, że w Polsce to się nie daje łapówek. Na przykład zarejestrowało się teraz dwoje dzieci do Opola na Uniwersytet Państwowy na studia. Rodzice nie wierzą, mówią: „Kłamią, że nie trzeba dawać pieniędzy! Lepiej do prywatnych [uczelni zapisać], bo w prywatnych płacisz. Lepiej zapłacić i mieć spokój". Żeby nic nie trudzić się, żeby nic nie obstawiać za swoim! To nasza bieda będzie, póki się naród nie opamięta, że musi mieć swoją godność najpierw. Po to jest ta rewolucja. Jakoś musi się to zgadzać jedno z drugim ${ }^{15}$.

Ci, którzy dokonywali rewolucji, są dla rozmówców nadzieją na lepszą przyszłość dla Ukrainy, są ludźmi z ideami, godnością, kochającymi swoją ojczyznę. Walczący na wschodzie kraju i ci, którzy wywalczyli nową władzę, w opowieściach byli ukazywani jako bohaterowie, którzy mają być gwarantem zmieniającego się społeczeństwa, nowej ukraińskiej tożsamości opartej na pamięci o rewolucji. Są buntownikami wobec starych zasad, starej zepsutej korupcją polityki państwa. Jedna z kobiet, wspominając o lokalnym wykorzystywaniu władzy do celów prywatnych, zaznaczyła:

Tamci siedzą, dobrze im na stołkach. Coś młodzi ludzie chcą zrobić, to tamtym się nie chce, bo tak jest im wygodnie. Oj poczekają... Przyjadą ci, co walczą i przegonią tą władze, pokażą, że można inaczej żyć. Bez łapówek, dziadostwa, żyć z ideą ${ }^{16}$.

Walczący na wojnie a także ci, którzy brali udział w Euromajdanie, już dziś są bohaterami. W każdym większym mieście zachodniej Ukrainy w miejscach, w których odbywały się manifestacje, znajduje się ściana pamięci, na której umieszono zdjęcia i podstawowe dane o osobach, które zginęły podczas Euromajdanu. Pod zdjęciami palą się znicze i leżą kwiaty. Niektóre ze zdjęć są zdjęciami pośmiertnymi. Także informacje dotyczące konfliktu na Ukrainie zawierają sceny strzelania do cywilów, ukazywane są zmasakrowane ciała z zasłoniętymi twarzami. Obrazy mają przemówić do widzów, ukazać tragizm wydarzeń, które dotyczą całego narodu ukraińskiego. W ukraińskiej telewizji zdjęcia ciał ofiar, żołnierzy i zbiórka funduszy na kamizelki kuloodporne, jedzenie, lekarstwa świadczą o charakterze tego konfliktu, w który zaangażowany jest cały kraj. Każdy z rozmówców określał go mianem wojny rosyjsko-ukraińskiej:

A jak mówią w Polsce na to, co się dzieje na wschodzie? U nas na początku było, że separatyści, autonomie, inna mentalność ale później gdy zaczęli brać do wojska chłopców, gdy wracały trumny, to okazało się, że to nie konflikt a wojna i to nie domowa, ale między Rosją a Ukrainą, tylko w piękne słowa obrana. Gdy ktoś nie wierzy, to oglądnie wiadomości, a tam słowa żołnierzy mówiących: „To nie jest walka separatystów, to wojna, nie wojna domowa ale wojna z Rosją. Uwierzcie, że to wojna", rozwiewają wszelkie wątpliwości ${ }^{17}$.

15 Kobieta, II pokolenie, Brzeżany.

16 Kobieta, II pokolenie, Brzeżany.

17 Mężczyzna, Il pokolenie, Brzeżany.
} 
Jednak wojna nie jest widziana tylko z perspektywy medialnych wiadomości i obrazów, ale także już wpływa na życie mieszkańców zachodniej Ukrainy. Jednym z efektów konfliktu jest napływ uciekających przed wojną mieszkańców wschodnich terenów Ukrainy na tereny centralnej i zachodniej części kraju. Nieznana liczba uchodźców, szacowana na setki tysięcy, uciekła z terenów wschodnich - obwodu ługańskiego i donieckiego, spowodowało to sytuację kryzysową w innych obwodach. Zazwyczaj rozmówcy poruszali tę kwestię w kontekście spraw dnia codziennego, problemów z zapisami do przedszkoli i szkół z powodu nadmiaru dzieci, punktów pomocy dla uchodźców i wzrostu cen nieruchomości na zachodniej Ukrainie. Interesujące wydaje się porównanie przez jednego ze starszych mężczyzn uchodźców ze wschodu do Niemców opuszczających po wojnie zachodnie ziemie Polski:

Nawet nam wujko po wojnie z Polski paczki przysyłat, bo tam Niemcy uciekali i wszystko zostawiali. Tak jak kiedyś uciekali, tak teraz uciekają do nas [z terenów wschodnich]. Przyjeżdżają tu, daj im pracę, daj im wszystko, a nasze dzieci biorą tam na miejscu. Takich biorą co to dwadzieścia, dwadzieścia trzy lata [mają], co on rozumie o wojnie? A pchają tam i stamtąd trupy przywożą, trumny. Tam ich wrzucają niekiedy do grobów masowych i nawet nie wiedzą, ile ich jest, tych trupów ${ }^{18}$.

Mężczyzna zaznacza swoistą niesprawiedliwą wymianę ludności. Ze wschodu przyjeżdżają całymi rodzinami uchodźcy, natomiast podczas powszechnej mobilizacji do wojska wstępują młodzi ludzie, którzy "nie znają wojny”. Ostatnie zdanie mówiące o nieokreślonej liczbie ofiar ukraińskich pojawiało się w wielu wypowiedziach. Zaznaczano, że w ukraińskich mediach nie podaje się łącznej liczby ofiar, tylko liczbę poległych i rannych w danym dniu czy tygodniu. Bardzo często mówiono także o celowości takiej dezinformacji:

Tu [we wsi] było spotkanie w niedzielę, ja miałam pójść, ale nie poszłam, to mówili nie słuchajcie tego telewizora, bo tam mówią tylko cząstkę. Ci, których dzieci na wojnie już walczą, to oni nie wierzyli telewizji. Mówili: „Tam miliony giną, tam ich po prostu rzucają do zbiorowych mogit. Paniki w narodzie nie chcą". Nie wiadomo, ilu tam ludzi poginęło ${ }^{19}$.

Aneksja Krymu i konflikt rosyjsko-ukraiński spowodowały strach ludzi o przyszłość. Rozmówcy, którzy przeżyli II wojnę światową, wspominali o zazębieniu się historii, o tym, że historia zatacza koło: dawni wrogowie nadal atakują, dawna wrogość się nie wypaliła, ale dziś jest wykorzystywana do niszczenia wschodniej części Ukrainy.

\section{SEPARATYŚCI, ŻOLNIERZE ROSYJSCY I MIESZKAŃCY WSCHODNIEJ UKRAINY, CZYLI OBRAZY "OBCEGO"}

Zajmując się wpływem doświadczeń wojennych na kształtowanie się świadomości i opinii rozmówców, należy przyjrzeć się definiowaniu przez nich "obcego", ponieważ wojna przyczynia się do ugruntowania zasobów interpretacyjnych charakterystycznych dla grup narodowych, wzmacniania stereotypów i uprzedzeń (Kaźmierska, 1999, ss. 53-54). W przypadku konfliktu rosyjsko-ukraińskiego w rozmowach możemy zauważyć trzy typy "obcego". Są nimi: separatyści, czyli mieszkańcy Wschodniej Ukrainy, którzy walczą o przynależność do Rosji; żołnierze wojsk Federacji Rosyjskiej, którzy pomagają separaty-

18 Mężczyzna, I pokolenie, Haluszczyńce

19 Kobieta, I pokolenie, Haluszczyńce. 
stom; w pewnym stopniu obcymi są także mieszkańcy Ukrainy Wschodniej. Podczas rozmów zazwyczaj winą za wojnę obarczano Federację Rosyjską, tylko w kilku przypadkach wspomniano o ludności cywilnej, która opowiadała się za przynależnością do strefy wpływów Rosji. Mimo że rozmówcy nie doświadczyli bezpośrednio działań konfliktu rosyjsko -ukraińskiego, określali wojska Federacji Rosyjskiej jako okupantów, nawiązując tym samym do historii okupacji sowieckiej w czasie II wojny światowej, wspominając nawet wydarzenia przekazywane w pamięci rodzinnej o czasach I wojny światowej. Jedna z kobiet, opowiadając o charakterze rosyjskiej władzy, porównała ją do działań bolszewików:

Kiedyś babcia mi mówiła, że jak była I wojna, to kilkadziesiąt dni była samodzielna Ukraina. Jak przyszli, to dobrze było, pomagali biednym. A potem Ukrainę zrzucili i przyszyli Moskale. To mówili, że gospodarzy do ławek przywiązywali i bili za to, że oni brali pomoc od tych Ukraińców. A mówiła babcia, że była prawdziwa Ukraina przez te dni, dobrze wtedy było, szanowali ludzi wszystkich. Kto nie mógł pracować to pomagali. Taki jeden starszy człowiek, biedny, nie miał ręki, to mu z gliny zrobili i koło chałupy porobili, że miał gdzie mieszkać. A później przyszli Moskale pobili go, poharatali wszystko. Jego zabili, zmarł na ławce, to właśnie Moskale. Teraz też na wschodzie Moskale się rządzą ${ }^{20}$.

W tym fragmencie opowieści zauważamy podział na dobrych gospodarzy Ukraińców i złych bolszewików, którzy bezwzględnie niszczą, mordują ludność lokalną. Według rozmówczyni są „źli z natury”, przywołana historia ma być argumentem potwierdzającym w opowieści zepsucie narodu rosyjskiego. Kobieta, opowiadając i przywołując wspomnienia swojej babci z 1917 roku, ukazuje nacjonalistów ukraińskich jako dobrych ludzi, którzy pomagali biedniejszym, chcieli zaprowadzić ład społeczny i tolerancję. Wspomina, że wraz z końcem niepodległej Ukrainy, skończyły się czasy szacunku i bezinteresownej pomocy, a nastały ponownie czasy władzy bolszewików, którzy w narracji są ukazani jako bezwzględnie źli, bezsensownie niszczący domostwa czy mordujący ludzi dla zabawy.

Pokolenie pamiętające II wojnę światową obarczało winą za sytuację na Wschodzie Ukrainy specyfike charakteru społeczeństwa rosyjskiego, przykładem tego były także opowieści, w których pojawiał się stereotyp żołnierza sowieckiego. Przykładem jest opowieść kobiety o chwili zesłania na Sybir:

Jak przyszli Moskale po nas w 1941, ciocia otworzyła okno, bo bardzo pies szczekał, on powiedział: „Będę strzelać!”. I wszystko. Pytamy: „Za co, dokąd?”. „Za dużo nie gadaj”... Teraz jak separatyści tam, to tacy sami separatyści jak Moskale wtedy, tak samo przyszli i zniszczyli. Jak zniszczą to dalej pójdą i dalej będą niszczyć. No chyba, że świat przyjdzie z pomocą, to inaczej może będzie ${ }^{21}$.

Rozmówczyni wiąże oba wydarzenia: zsyłkę na Sybir i konflikt rosyjsko-ukraiński, agresorami w obu przypadkach w jej opowieści są "Moskale i separatyści”, którzy traktowani są jako jedna grupa. W opowieści są ukazywani jako ludzie z zewnątrz, „ci, którzy przyszli", a nie jako mieszkańcy wschodnich terenów Ukrainy. W narracjach, które odnoszą się do porównywania charakteru obu wojen, agresorzy są określani jako nieludzie, zabijają tylko dla pieniędzy bądź dla zabawy. Ich wizerunek jest definitywnie negatywny (Kabzińska, 1999, s. 82). Dominuje ukazanie ich jako dzikich, pijanych, odurzonych narkotykami żołnierzy, którzy nie walczą dla idei. Rozmówcy nie oddzielali wojsk rosyjskich od grup separatystów, traktowano ich na równi jako grupy podlegające władzy rosyjskiej. W narra-

20 Kobieta, I pokolenie, Czortków.

21 Kobieta, I pokolenie, Raj, wywiad w języku ukraińskim. 
cjach pojawiały się określenia: „ci separatyści oni tylko nażreć się chcą"22, „to nie zwykli ludzie tylko bandyci, strzelają, rabują"23. ,"Nasłali jakąś bandę i rabują, z Azji trochę ich jest, tych co niby wyzwalają" 24 , „Tutaj do nas wojna dojdzie to my przepadli, przecież on wypuścił cały kryminalitet, te bandyty" 25 .

Agresorzy są dzicy, nieludzcy, nieracjonalni, opowiadający podkreślali tę obcość poprzez wyraz pogardy. Łatwiej bowiem myśleć o wrogu jako o dzikusie, który najpierw zabija, a później pokazuje zwłoki, efekt swojej pracy całemu światu, chwali się morderstwem (Sontag, 2010, s. 85). W czasie wojny radykalizuje się tożsamość ofiary i sprawcy, sam konflikt jawi się jako czarno-biały. Można mieć wrażenie, że ten podział spowodowany przez konflikt dzieli ludzi na tych, których życie jest wartościowe - walczą za idee, za wolność i tych, których życia nam nie żal. Jak pisze Butler: „Po życiu, którego nam nie żal nie będziemy odbywać żałoby, ponieważ $w$ istocie nigdy nie żyło, tzn. nigdy nie liczyło się jako życie" (Butler, 2011, s. 89). Dla walczących widok ciał ofiar, zniszczonych budynków powoduje poczucie strachu, ale i utwierdzenia w nienawiści wobec agresora. Dla bojowników tożsamość jest wszystkim, jest ukazaniem prawdy jednej ze stron, dlatego także w czasie wojny narastają nacjonalizmy. W opowieściach często zaznaczano, że wśród walczących są osoby z azjatyckiej części Federacji Rosyjskiej, co miało podważać tłumaczenia wejścia wojsk rosyjskich na teren Ukrainy jako walkę o życie rosyjskojęzycznej ludności. Nikt z rozmówców nie wierzył w tłumaczenie konfliktu na wschodzie Ukrainy, ciemiężeniem i prześladowaniem ludności wschodniej Ukrainy.

Tylko niektórzy zwracali uwage na inną mentalność mieszkańców Ukrainy Wschodniej i wierzyli w autentyczny protest sprzeciwiających się proeuropejskiej drodze Ukrainy. Według kilku z nich mieszkańcy wschodu byli ludźmi systemu sowieckiego, homo sovieticusami, którzy stali się "ofiarami” i "pionkami” w walce Rosji o teren wpływów.

To wszystko takie przewrócone na głowę. I teraz słucham, co oni mówią tam na wschodzie, do niedawna pokazywano te różne demonstracje "Rasija, Rasija”, wrzeszczeli w tym języku rosyjskim. Krzyczeli, że tu [na zachodniej Ukrainie] banderowcy. Inaczej mówimy, inaczej myślimy i mamy poukładane w głowie na zachodniej Ukrainie niż oni -tylko ta różnica. I oni nie żadni Rosjanie ale Ukraińcy, tylko to jest takie udawanie, taka komedia i za tą komedię zapłacili. Bardzo straszną cenę, nie warte było, teraz zaczynają trzeźwieć. Ci wszyscy co wracają, zaczynają odbudowywać tam te domy, w miejscach, w których już jest trochę spokojniej. Ludzie też ze Lwowa, z reszty Ukrainy składają się żeby można było ich jakoś przyjąć, jakoś pomóc tym, co wrócili. Przecież nie będziemy ich utrzymywać tutaj, mają wrócić do siebie, mają odbudować i żyć tam gdzie żyli. [...] Ci, co zostaną, muszą tutaj żyć tak, jak my żyjemy, zasymilować się, bo nikt im nie będzie ich cierpieć, ich postaw. Tutaj jest inna mentalność, tutaj był biedny region. Ludzie przyzwyczajeni, że trzeba ciężko pracować, a tam przemysłowe tereny, a jak wielki przemyst to i ludzie zjeżdżają by zarobić trochę większe pieniądze ${ }^{26}$.

W tym fragmencie mieszkańcy wschodniej Ukrainy są opisywani jako ludzie o innej mentalności niż na zachodzie, która jest stworzona przez schedę po socjalistycznym systemie. Przywiązanie protestujących ludzi na wschodniej Ukrainie do Rosji i ukazywanie tego w mediach rozmówczyni nazywa "głupotą", której efektem są działania wojenne, zniszczenia i ofiary. W cytacie zauważalny jest podział na "tych ze wschodu”: krzykliwych, leniwych, raptownych, i "tych z zachodu”: pracowitych i pokornych, choć jak wspomina kobieta, dzieli ich tylko inna mentalność, podejście do życia.

22 Kobieta, I pokolenie, Brzeżany.

23 Kobieta, II pokolenie, Raj, wywiad w języku ukraińskim.

24 Mężczyzna, I pokolenie, Haluszczyńce.

25 Mężczyzna, I pokolenie, Czortków.

26 Kobieta, II pokolenie, Czortków. 
W kilku opowieściach pojawiał się stereotyp Ukraińca i Rosjanina, który był wyttumaczeniem chęci zajęcia Ukrainy jako terytorium rosyjskich wpływów, kilkakrotnie pojawiło się ukazanie Ukraińców jako pracowitych, pokornych, dobrze gospodarzących, posiadających cechy, których według rozmówców brakuje narodowi rosyjskiemu:

Putin ma takie wielkie tereny tam, że nie może sobie z tym dać rady, po co mu Ukraina? Ale on bez Ukrainy nie może, za to że Ukraińcy są takie pracowite i więcej gospodarni a Ruski to jest taka wolność i wódka, tam u nas dużo Ukraińców pracuje, jadą do Moskwy pracować, to Putin widzi ${ }^{27}$.

Dzisiejsza „walka” o wolność rosyjskojęzycznej ludności na Ukrainie przypomina jeden z wariantów neoimperialnej polityki Rosji względem dawnych terenów ZSRR. Jednym z wariantów rozszerzenia imperium jest wykorzystanie "technologii" integrujących różnorodne etnosy i budowania za ich pomocą politycznego, nieetnicznego (kulturalnego) nacjonalizmu. Głównym narzędziem owych technologii byłaby szkoła, administracja, więzi gospodarcze, środki komunikacji masowej i wreszcie kultura masowa. Wielokrotnie w rozmowach zaznaczano imperialne podejście Rosji do państw powstałych po upadku ZSRR, podejście paternalistyczne, i to, że Rosja traktuje Ukraińców jako rosyjską grupę etniczną, "braci mniejszych" Rosjan:

Ukraina nie chce iść do Rosji, niech będzie jak jest, ale będziemy sami sobie robić, sami sobie, dla siebie. A nie sąsiad nam każe co mamy robić. O to niezależność jest! To ważne dla ludzi.

Ale my nie byliśmy niezależni, Rosja starszy brat, a my kto? Małorusy! A my nie Ukraińcy, tylko Małorusy ${ }^{28}$.

We fragmencie pojawia się dyskurs tożsamościowy Rosji polegający na micie wspólnoty wschodnich Słowian, którzy mają wspólne korzenie dziedzictwa Rusi Kijowskiej. Jest to jeden z najsilniejszych mitów Federacji Rosyjskiej, który jest obecny zarówno w historiografii radzieckiej jak i współczesnej (Bachórz, 2013, s. 87). Rozmówcy zwracali uwage na zuchwałe działania Władimira Putina i traktowanie Ukrainy jako terytorium nie odrębnego narodu, ale dawnych kolonii.

\section{ZAKOŃCZENIE}

Podział Ukrainy na dwie części jest pewną generalizacją. Do czasów Euromajdanu grupy proeuropejskie i proradzieckie był mniejszością. Rzeczywistą większość stanowiła amorficzna grupa, której kwestie orientacji kraju nie obchodziły, pozostała ona niezdecydowana i uchylała się od odpowiedzi (Studenna, 2009, s. 106). W czasie konfliktu tożsamość obywateli Ukrainy uległa radykalizacji, Euromajdan i wydarzenia związane z kryzysem krymskim oraz konfliktem w Donbasie stały się elementem pamięci, który już dziś wpływa na kształtowanie tożsamości ukraińskiej. Konflikt rosyjsko-ukraiński miał wpływ także na ludność pochodzenia polskiego zamieszkałą na terenie Zachodniej Ukrainy. Podczas badań terenowych rozmówcy mówili, że w chwili dziejącej się na wschodzie kraju wojny, bycie obywatelem Ukrainy jest dla nich najważniejszym elementem ich tożsamości. Najstarsze pokolenie w opowieściach używało ram narracyjnych, którymi były obie wojny, zaznaczano powiązania między dwoma wydarzeniami, podając jako przykłady wizerunek

27 Kobieta, I pokolenie, Raj.

28 Kobieta, II pokolenie, Czortków, wywiad w języku ukraińskim. 
"obcych": okupanta sowieckiego z II wojny światowej, sowieckiego, a później rosyjskiego żołnierza wkraczającego na wschodnie terytoria Ukrainy. W domach i w przestrzeni publicznej pojawiły się barwy i symbole narodowe będące znakiem jedności z walczącymi o proeuropejską Ukrainę. Wojna wpłynęła także na sferę emocji, mimo iż rozmówcy nie mieszkali na terenach objętych walkami, mają one silny wpływ na ich życie. Kryzys, w jakim znalazła się Ukraina po rewolucji, spowodował wzrost cen żywności, upadek hrywny, a także napływ uchodźców ze wschodu. Wielokrotnie wspominano o strachu przed przyszłością, młodzi ludzie zaznaczali, iż niepewność jutra wpływa na ich decyzje życiowe. Polska w opowieściach o przyszłości młodego pokolenia Polaków na Ukrainie istnieje jako potencjalny kraj w chwili ucieczki z kraju objętego wojną. Powszechna mobilizacja mężczyzn do wojska stale uświadamia rozmówcom, że konflikt nadal trwa i nosi miano wojny. Powszechny strach przed śmiercią najbliższych i kryzysowa sytuacja w kraju powodują poczucie zagrożenia życia, wpływają także na identyfikację ludności na Ukrainie mającej polskie korzenie, która w obliczu konfliktu na pierwszym miejscu określa siebie jako obywateli państwa Ukrainy, państwa objętego wojną

\section{BIBLIOGRAFIA}

Assmann, A. (2013). Między historią a pamięcią: Antologia. Warszawa: Wydawnictwa Uniwersytetu Warszawskiego.

Bachórz, A. (2013). Mit wschodnich Słowian: Z tożsamościowych dyskursów Białorusi, Rosji i Ukrainy. Rocznik Instytutu Europy Środkowo-Wschodniej, 11(2), 87-98. Pobrano z http://www.iesw.lublin.pl/rocznik/pliki/Rocznik_2013-199.pdf

Butler, J. (2011). Ramy wojny: Kiedy życie godne jest opłakiwania. Warszawa: Instytut Wydawniczy Książka i Prasa.

Eberhardt, P. (1994). Przemiany narodowościowe na Ukrainie w XX wieku. Warszawa: Biblioteka Obozu.

Filipowski, P. (2010). Historia mówiona i wojna: Doświadczenie obozu koncentracyjnego w perspektywie narracji biograficznej. Wrocław: Wydawnictwo Uniwersytetu Wroctawskiego.

Geertz, C. (2011). Zdobywając doświadczenia, autoryzując siebie. W V. W. Turner \& E. M. Bruner (Red.), Antropologia doświadczenia (ss. 393-402). Kraków: Wydawnictwo Uniwersytetu Jagiellońskiego

Hrycak, J. (2000). Historia Ukrainy 1772-1999: Narodziny nowoczesnego narodu. Lublin: Wydawnictwo Instytutu Europy Środkowo-Wschodniej.

Kabzińska, I. (1999). O słowach, emocjach i polskiej krzywdzie. Etnografia Polska 43(1-2), 81-95.

Kaźmierska, K. (1999). Doświadczenia wojenne Polaków a kształtowanie tożsamości etnicznej: Analiza narracji kresowych. Warszawa: Wydawnictwo IFiS PAN.

Kukuczka, J. (2010). Antropologia na wojennej ścieżce: Wojny i konflikty etniczne jako wyzwanie dla współczesnego etnologa. W F. Wróblewski, Ł. Sochacki, \& J. Steblik (Red.), Antropologia zaangażowana (?) (ss. 75-84). (Zeszyty Naukowe Uniwersytetu Jagiellońskiego 1309: Prace Etnograficzne, 38)

Riabczuk, M. (2004). Dwie Ukrainy. Wrocław: Kolegium Europy Wschodniej.

Smith, A. D. (2009). Kulturowe podstawy narodów: Hierarchia, przymierze i republika. Kraków: Wydawnictwo Uniwersytetu Jagiellońskiego. 
Sontag, S. (2010). Widok cudzego cierpienia. Kraków: Wydawnictwo Karakter.

Studenna, M. (2009). Fenomen ambiwalencji społecznej na Ukrainie w latach 1991-2004. W P. Adamczewski (Red.), Konflikty na obszarze byłego ZSRR (ss. 101-107). Poznań: Wydawnictwo ESUS.

Żakowska, M. (2009). Ukraina po 1991 roku - model państwa narodowego i jego uwarunkowania. W P. Adamczewski (Red.), Konflikty na obszarze byłego ZSRR (ss. 109-117). Poznań: Wydawnictwo ESUS. 